\title{
Zr-Laponite pillared clay-based nickel catalysts for methane reforming with carbon dioxide
}

\author{
Zhengping Hao ${ }^{\text {a,b, }}$, H.Y. Zhu ${ }^{\text {a }}$, G.Q. Lu ${ }^{\text {a }}$ \\ a Department of Chemical Engineering, University of Queensland, St. Lucia, Qld 4072, Australia \\ ${ }^{\mathrm{b}}$ Research Center for Eco-Environmental Science, Chinese Academy of Sciences, Beijing 100085, PR China
}

Received 16 May 2002; received in revised form 30 August 2002; accepted 13 September 2002

\begin{abstract}
Zr-Laponite pillared clays were prepared and used as supports of nickel catalysts for the methane reforming reaction with carbon dioxide to synthesis gas. The structural and textural characteristics of supports and catalysts were systematically examined by $\mathrm{N}_{2}$ adsorption/desorption and X-ray diffraction (XRD), X-ray photoelectron spectroscopy (XPS), and transmission electron spectroscopy (TEM) techniques. The catalytic performance and carbon deposition were investigated. It is found that $\mathrm{Zr}$-Laponite pillared clays are promising catalyst supports for carbon dioxide reforming of methane. The pore structure and surface properties of such supports greatly affect the catalytic behaviors of catalysts derived. Carbon deposition on catalysts was also affected by the property and structure of supports. The sintering of nickel metal and zirconia was another factor responsible for catalyst deactivation. This new-type nickel supported catalyst $\mathrm{Ni} / \mathrm{Zr}$-Laponite(8), with well-developed porosity, gave a higher initial conversion and a relatively long-term stability, and is therefore a promising catalyst for potential application to carbon dioxide reforming of methane to synthesis gas.
\end{abstract}

(c) 2002 Elsevier Science B.V. All rights reserved.

Keywords: Methane reforming; Nickel catalysts; Mesoporous oxide support

\section{Introduction}

The reforming of methane with carbon dioxide has gained growing interest as it can produce synthesis gas with a $\mathrm{H}_{2} / \mathrm{CO}$ ratio around 1 , which is suitable for the Fischer-Tropsch synthesis. This reaction has important environmental implications, since both methane and carbon dioxide are greenhouse gases. Interestingly, this process exhibits a certain potential to be used as a thermochemical heat-pipe for recovery, storage and transmission of solar and other renewable energy sources. However, so far no industrial technol-

\footnotetext{
* Corresponding author.

E-mail address: zpinghao@ mail.rcees.ac.cn (Z. Hao).
}

ogy has been established, due to the serious problem of catalyst deactivation.

Most group VIII metals are catalytically active for this reaction. One serious problem is the catalyst deactivation due to carbon deposition, especially for $\mathrm{Ni}$ catalysts [1]. Although noble metals suffer less coking than nickel, nickel is more attractive in industrial applications due to its inherent availability and lower cost in comparison to noble metals. Therefore, development of Ni catalysts with little or no coking deactivation is of great interest as is the development of industrial applications of this process.

Several studies have shown that the nature of the support employed has an important influence on catalytic performances. Among the supports, such 
as $\mathrm{Al}_{2} \mathrm{O}_{3}, \mathrm{SiO}_{2}, \mathrm{TiO}_{2}, \mathrm{MgO}, \mathrm{ZrO}_{2}, \mathrm{CeO}_{2}, \mathrm{La}_{2} \mathrm{O}_{3}$, clays, and zeolites, $\mathrm{Al}_{2} \mathrm{O}_{3}$ supported nickel catalysts showed the highest initial activities [2]. However, they also suffered serious deactivation. Although several researchers have studied Ni-based catalysts, such as $\mathrm{Ni} / \mathrm{MgO}, \mathrm{Ni} / \mathrm{La}_{2} \mathrm{O}_{3}, \mathrm{Ni} / \mathrm{ZrO}_{2}$, and $\mathrm{Ni} /$ clay, which to some degree could be effective catalysts for $\mathrm{CO}_{2}$ reforming of methane in terms of conversion and stability. However, there is still a long way to go before their industrial applications can be realized.

Recently, the pillared clay or $\mathrm{ZrO}_{2}$ supported nickel catalysts have generated increasing interest. Wang et al. [3] studied clays (montmorillonite and bentonite) and pillared clay-supported nickel catalysts for the $\mathrm{CO}_{2}$ reforming of methane. Their results showed that pore structure and surface properties of supports greatly affect the catalytic activity of catalysts. The catalysts supported on the mesoporous clays or pillared clay are obviously superior to those supported on the microporous supports. Hwang et al. [4] reported that alumina pillared laponite clay is a promising catalyst support for this reaction. Choudhary et al. [5] also studied $\mathrm{CO}_{2}$ reforming and simultaneous $\mathrm{CO}_{2}$ and steam reforming of methane over $\mathrm{Co}_{x} \mathrm{Ni}_{1-x} \mathrm{O}$ supported on macroporous silica-alumina precoated with $\mathrm{MgO}$.

Seshan et al. [6] studied serial $\mathrm{Ni} / \mathrm{ZrO}_{2}$ catalysts for the $\mathrm{CO}_{2}$ reforming of methane and found that catalysts with high loading nickel deactivated quickly because of coking. Lercher et al. [7] reported that $\mathrm{ZrO}_{2}$ was crucial for platinum and nickel catalysts to minimize coke deposition under $\mathrm{CO}_{2} / \mathrm{CH}_{4}$ reforming condition, and a well-dispersed $\mathrm{ZrO}_{2}$ supported nickel catalyst seemed to be a viable alternative to noble metal catalysts. Wei et al. [8] researched $\mathrm{Ni} / \mathrm{ZrO}_{2}$ catalysts with different preparations for $\mathrm{CO}_{2}$ reforming of methane and found that catalytic stability depends greatly on the preparation method and the support precursor. They stated that the catalyst prepared by impregnation of ultra-fine $\mathrm{Zr}(\mathrm{OH})_{4}$ particles with nickel nitrate showed especially high and extremely stable activity for syngas production. $\mathrm{Li}$ et al. $[9,10]$ studied the performance of $\mathrm{CO}_{2}$ reforming of methane and carbon deposition on $\mathrm{Ni} / \mathrm{ZrO}_{2}$ catalysts by means of dilution methods for catalyst and reactants.

Clay materials are interesting materials as catalyst supports, not only due to their great abundance and low cost but also because of the particular properties and structures they possess [3]. The pore structure of pillared interlayed clays (PICLs) depends on the oxide pillars and preparation methods. Furthermore, by loading cations, the surface property of PICLs can be altered and their pore structure can be fine-tuned [11]. In recent years, intensive studies on the catalytic applications of pillared clays have been reported [12]. Zirconia can be used as a support for reforming catalysts because it has Lewis acidic sites with a very low concentration to minimize the carbon formed on the surface, which also may increase the possibility of operation at high temperatures [13].

In this paper, we report more detailed studies on zirconia pillared laponite clay supported nickel catalysts for the carbon dioxide reforming of methane. In this investigation, effects on catalytic activity and stability were studied, such as support, metal loading and preparation method of catalysts. The catalyst structure and formed carbon species were characterized by $\mathrm{N}_{2}$ adsorption/desorption, X-ray diffraction (XRD), X-ray photoelectron spectroscopy (XPS), transmission electron spectroscopy (TEM), and temperature-programmed oxidation (TPO).

\section{Experiment}

\subsection{Catalyst preparation}

\subsubsection{Support preparation}

The starting clay (supplied by Fernz Specialty Chemicals, Australia) has a cation exchange capacity (CEC) of $55 \mathrm{meq}$. per $100 \mathrm{~g}$ of clay. Zirconium oxychloride $\left(\mathrm{ZrOCl}_{2} \cdot 8 \mathrm{H}_{2} \mathrm{O}\right.$, Fluka Co.) was used as the zirconia source. A type nonionic PEO surfactant (Tergitol 15S-9), from Union Carbide Chemicals and Plastics Co., was used in this study. The PEO surfactants have a general chemical formula of $\mathrm{C}_{12-14} \mathrm{H}_{25-29} \mathrm{O}\left(\mathrm{CH}_{2} \mathrm{CH}_{2} \mathrm{O}\right)_{n} \mathrm{H}$. An amount of $16.1 \mathrm{~g}$ of $\mathrm{ZrOCl}_{2} \cdot 8 \mathrm{H}_{2} \mathrm{O}$ was dissolved in $30 \mathrm{ml}$ of water, and then the solution was diluted. This solution was refluxed for $1 \mathrm{~h}$ under stirring. Four grams of laponite was dispersed into $200 \mathrm{ml}$ of water, and this suspension was stirred until it became clear. A certain amount of surfactant (TS-9) was added into the laponite suspension. The stirring was prolonged for $2 \mathrm{~h}$ to allow sufficient mixing. One hundred milliliters of the refluxed $\mathrm{ZrOCl}_{2}$ solution was dropped into the above solution under vigorous stirring. The suspen- 
sion was transferred into an autoclave and maintained at $100{ }^{\circ} \mathrm{C}$ for 2 days. White precipitate was recovered from the mixture by centrifuging and washed with deionized water until it was free of $\mathrm{Cl}^{-}$ions. The wet cake was dried in air and calcined at $500{ }^{\circ} \mathrm{C}$ for $20 \mathrm{~h}$. The heating temperature was raised at a rate of $2{ }^{\circ} \mathrm{C} / \mathrm{min}$. The amounts of surfactant added in the preparation process were $12,8,4$, and $0 \mathrm{~g}$ for samples Zr-Laponite(12), Zr-Laponite(8), Zr-Laponite(4), and Zr-Laponite(0), respectively.

\subsubsection{Catalyst preparation}

Catalysts were prepared by the incipient wetness impregnation method with aqueous solutions of nitrates as metal precursors. The solids were dried overnight in air at $105^{\circ} \mathrm{C}$, and then calcined at $500^{\circ} \mathrm{C}$ in air for $4 \mathrm{~h}$ in order to realize the complete decomposition of the nitrate. After this treatment, the catalyst was reduced at $500{ }^{\circ} \mathrm{C}$ in a steam of $50 \% \mathrm{H}_{2} / \mathrm{N}_{2}$ for $2 \mathrm{~h}$. The nickel metal loading of catalyst was $9 \mathrm{wt} . \%$, except where stated otherwise.

\subsection{Catalyst characterization}

The surface area and pore size of catalysts were determined by nitrogen adsorption using a NOVA 1200 (Quantachrome, USA) at $-196^{\circ} \mathrm{C}$. The sample was degassed under vacuum of $10^{-2}$ Torr at $230^{\circ} \mathrm{C}$ for $4 \mathrm{~h}$ in high vacuum before the measurement. The surface area $\left(S_{\mathrm{BET}}\right)$ was calculated using the BET equation. The total pore volume was derived from the amount of adsorption at a relative pressure close to unity. The average pore size $\left(D_{\mathrm{p}}\right)$ was estimated from the pore volume assuming a cylindrical pore geometry using the equation: $R_{\mathrm{p}}=2 V_{\text {liq }} / S$, where $V_{\text {liq }}$ is the volume of liquid adsorbate contained in the pores and $S$ is the BET surface area.

XRD powder diffraction measurements were performed on a PW 1050 Diffractometer Automation Site 122D. The Scherrer equation was used to estimate the related crystallite size.

XPS analyses were carried out using a PHI Model $560 \mathrm{XPS} / \mathrm{SAM} / \mathrm{SIMS}$ I multitechnique surface analysis system located at the Brisbane Surface Analysis Facility of the University of Queensland. The system incorporates a PHI model 25-270AR CMA electron energy analyzer and a dual $\mathrm{Mg} / \mathrm{Al} \mathrm{X}$-ray source. $\mathrm{Mg}$ $\mathrm{K} \alpha \mathrm{X}$-rays were used during analysis, where XPS survey (wide) scans were taken at a pass energy of $100 \mathrm{eV}$ and multiplex (narrow) scans of selected elements were taken at $25 \mathrm{eV}$. Atomic concentrations were calculated from peak areas using linear baselines and experimentally determined sensitivity factors.

Transmission election microscopy (TEM) was performed using a JEOL 2010 microscope operating at $200 \mathrm{keV}$. Samples were prepared by crushing under acetone. The slurry was dispersed on holey carbon film supported by a copper grid.

Temperature-programmed oxidation (TPO) experiments of carbon species formed on the catalyst were conducted on a thermogravimetric analyzer (Shimadzu-50) in air with a flow rate of $20 \mathrm{ml} / \mathrm{min}$. The temperature was first raised to $110^{\circ} \mathrm{C}$, kept there for $1 \mathrm{~h}$, and then raised to $800^{\circ} \mathrm{C}$ with a heating rate of $5^{\circ} \mathrm{C} / \mathrm{min}$.

\subsection{Catalytic performances}

Catalytic reaction experiments were conducted in a vertical fixed-bed reactor made of a quartz tube under atmospheric pressure. An amount of $0.2 \mathrm{~g}$ catalyst was placed in the quartz tube. A thermocouple was placed in the tube with one end touching on the catalyst in order to measure the bed temperature. The mixture of reactants of methane and carbon dioxide with ratio of $1: 1$ was fed into the reactor at the flow rate of $60 \mathrm{ml} / \mathrm{min}(\mathrm{GHSV}=18,000 \mathrm{ml} / \mathrm{g} \mathrm{h}$ ). The analyses of reactant/product mixtures were carried out using an on-line gas chromatograph (Shimadzu-17A) equipped with a thermal conductivity detector. A carbosphere (80-100 mesh) column was used to separate $\mathrm{H}_{2}, \mathrm{CO}$, $\mathrm{CH}_{4}$, and $\mathrm{CO}_{2}$. Prior to each reaction run, the catalyst was reduced in situ at $500{ }^{\circ} \mathrm{C}$ in $50 \% \mathrm{H}_{2} / \mathrm{N}_{2}$ for $2 \mathrm{~h}$. The activities of catalysts were investigated at temperatures between 500 and $800^{\circ} \mathrm{C}$, and stability tests were conducted at a certain reaction temperature only. Methane and carbon dioxide used were ultra high purity gases supplied by Matheson, USA.

\section{Results and discussion}

\subsection{Surface area and pore size of supports and catalysts}

It has been found that the support and methods of catalyst preparation influence the catalyst perfor- 
Table 1

Variation in pore structure of supports and catalysts prepared

\begin{tabular}{lllr}
\hline Sample & Surface area $\left(\mathrm{m}^{2} / \mathrm{g}\right)$ & Pore volume $\left(\mathrm{cm}^{3} / \mathrm{g}\right)$ & Pore diameter $(\mathrm{nm})$ \\
\hline $\mathrm{Zr}$-Laponite $(0)$ & 211.4 & 0.174 & 3.3 \\
$\mathrm{Zr}$-Laponite(4) & 390.8 & 0.360 & 3.7 \\
$\mathrm{Zr}$-Laponite $(8)$ & 458.6 & 0.41 & 4.1 \\
$\mathrm{Zr}$-Laponite(12) & 435.9 & 0.413 & 3.8 \\
$\mathrm{Al}_{2} \mathrm{O}_{3}$ & 112 & 0.286 & 10.3 \\
$\mathrm{Ni} / \mathrm{Zr}$-Laponite $(0)\left(500^{\circ} \mathrm{C}\right)$ & 260.3 & 0.192 & 3.0 \\
$\mathrm{Ni} / \mathrm{Zr}$-Laponite $(0)\left(600^{\circ} \mathrm{C}\right)$ & 227 & 0.169 & 3.0 \\
$\mathrm{Ni} / \mathrm{Zr}$-Laponite $(8)\left(500^{\circ} \mathrm{C}\right)$ & 371.9 & 0.354 & 3.8 \\
$\mathrm{Ni} / \mathrm{Zr}$-Laponite $(8)\left(600^{\circ} \mathrm{C}\right)$ & 350 & 0.34 & 3.7 \\
$\mathrm{Ni} / \mathrm{Zr}-$ Laponite $(4)\left(500^{\circ} \mathrm{C}\right)$ & 330 & 0.306 & 3.8 \\
$\mathrm{Ni} / \mathrm{Zr}$-Laponite $(12)\left(500^{\circ} \mathrm{C}\right)$ & 356 & 0.337 & 3.8 \\
$4.5 \% \mathrm{Ni} / \mathrm{Zr}-$ Laponite $(8)\left(500^{\circ} \mathrm{C}\right)$ & 371.8 & 0.351 & 3.8 \\
$\mathrm{Ni} / \mathrm{Al}{ }_{2} \mathrm{O}_{3}$ & 118 & 0.230 & 7.8
\end{tabular}

mance for the carbon dioxide reforming of methane [1]. The surface area and pore structure of the support is important to the dispersion and structure of active phase on supports. The surface areas and pore sizes of supports and catalysts were studied by nitrogen adsorption. The results are listed in Table 1. The pillaring process greatly increases the surface area of these laponite materials. It was seen that, when the amount of the introduced surfactant was increased, the surface area of Zr-Laponite increased, until the Zr-Laponite(12) with a $12 \mathrm{~g}$ amount of surfactant in the pillaring process, when its surface area decreased. This indicates that the surfactant amount of $12 \mathrm{~g}$ is more than enough in the pillaring process. All these supports are mesoporous and have higher surface areas than $\gamma-\mathrm{Al}_{2} \mathrm{O}_{3}$. The surface area order of supports is Zr-Laponite(8) > Zr-Laponite(12) > Zr-Laponite(4) $>$ Zr-Laponite(0). The order of catalysts is similar to that of supports. The surface area of a catalyst treated at $500^{\circ} \mathrm{C}$ is higher than at $600^{\circ} \mathrm{C}$. It is also seen that the surface area of catalysts is generally reduced for those with highly porous structure.

\subsection{Catalytic activity for carbon dioxide reforming of methane}

The stoichiometric reforming reaction was conducted at atmospheric pressure and GHSV of $18000 \mathrm{ml} / \mathrm{g} \mathrm{h}$, and the catalytic performances of various $\mathrm{Zr}$-Laponite supported $\mathrm{Ni}$ catalysts were evaluated in a fixed-bed reactor in the temperature range of $500-800^{\circ} \mathrm{C}$.
The activity results of various catalysts are shown in Figs. 1-6. The conversion increases with the rise of the reaction temperature. The $\mathrm{CO}_{2}$ conversions were always higher than the $\mathrm{CH}_{4}$ conversions. This indicates that the reverse water gas shift reaction occurred in the reaction process. Figs. 1 and 2 give $\mathrm{CO}_{2}$ and $\mathrm{CH}_{4}$ conversions at various temperatures over catalysts obtained at different temperatures. Catalysts calcined and reduced at $500{ }^{\circ} \mathrm{C}$ have a higher catalytic activity than that obtained at $600^{\circ} \mathrm{C}$. Metal load-

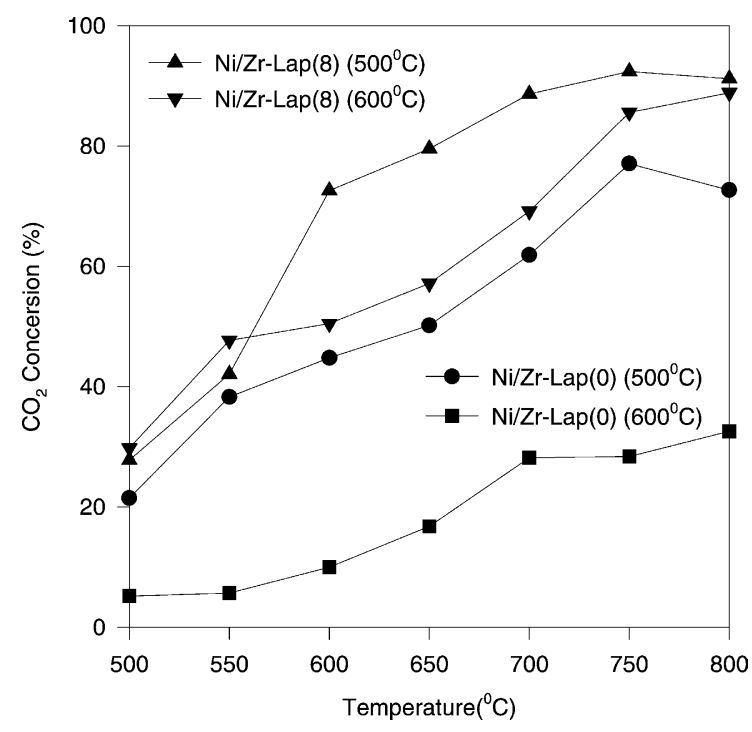

Fig. 1. $\mathrm{CO}_{2}$ catalytic conversions over $\mathrm{Ni} / \mathrm{Zr}$-Laponite catalysts. Reaction conditions: $\mathrm{CH}_{4} / \mathrm{CO}_{2}=1: 1, P=1 \mathrm{~atm}, F / W=$ $18,000 \mathrm{ml} / \mathrm{h}$ gcat. 


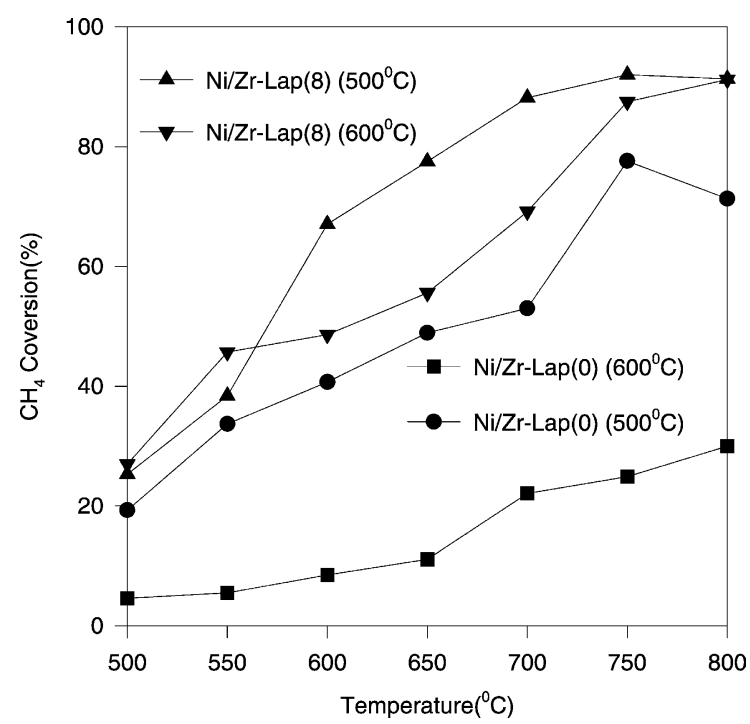

Fig. 2. $\mathrm{CH}_{4}$ catalytic conversions over various $\mathrm{Ni} / \mathrm{Zr}$-Laponite catalysts. Reaction conditions: $\mathrm{CH}_{4} / \mathrm{CO}_{2}=1: 1, P=1 \mathrm{~atm}$, $F / W=18,000 \mathrm{ml} / \mathrm{h}$ gcat.

ings on support also affect the activity of a catalyst, $\mathrm{Ni} / \mathrm{Al}_{2} \mathrm{O}_{3}$ catalysts with $6-12 \mathrm{wt} . \%$ nickel loading were investigated for $\mathrm{CO}_{2} / \mathrm{CH}_{4}$ reforming by Yan et al. [14]. As shown in Figs. 3 and 4, conversions of $\mathrm{CO}_{2}$ and $\mathrm{CH}_{4}$ increased with elevated $\mathrm{Ni}$ metal

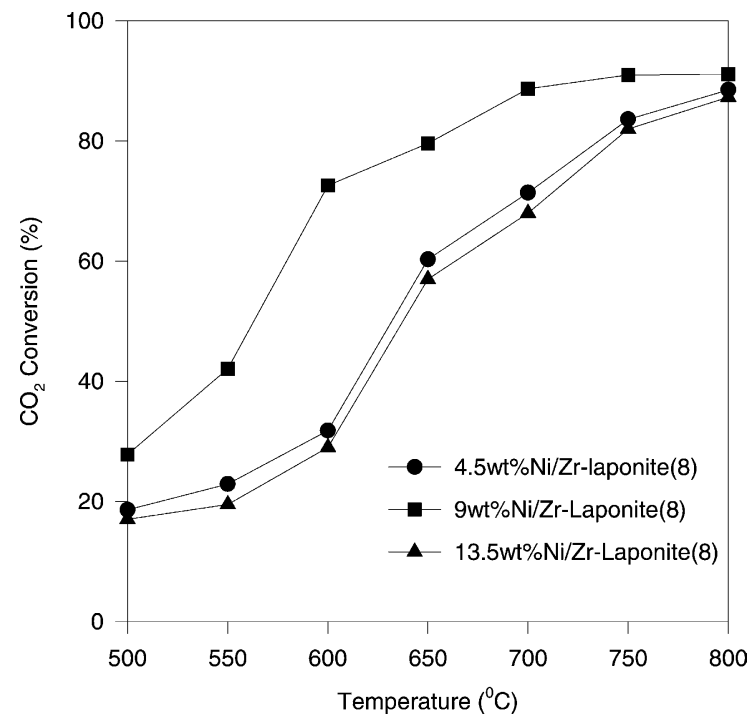

Fig. 3. $\mathrm{CO}_{2}$ catalytic conversions over various $\mathrm{Ni} / \mathrm{Zr}$-Laponite catalysts. Reaction conditions: $\mathrm{CH}_{4} / \mathrm{CO}_{2}=1: 1, P=1 \mathrm{~atm}$, $F / W=18,000 \mathrm{ml} / \mathrm{h}$ gcat.

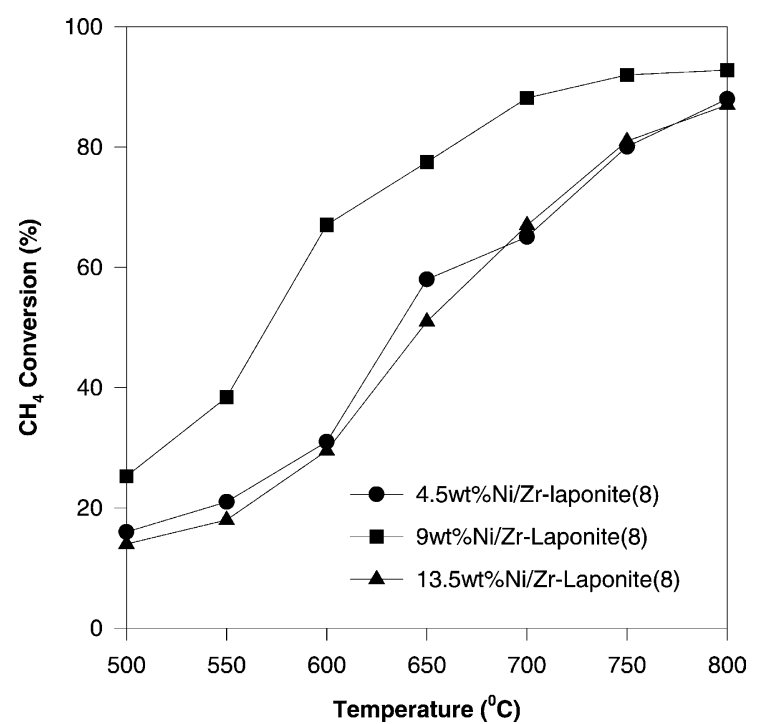

Fig. 4. $\mathrm{CH}_{4}$ catalytic conversions over various loading $\mathrm{Ni} / \mathrm{Zr}$-Laponite catalysts. $\mathrm{CH}_{4} / \mathrm{CO}_{2}=1: 1, \quad P=1 \mathrm{~atm}$, $F / W=18,000 \mathrm{ml} / \mathrm{h}$ gcat.

loading from 4.5 to $9 \mathrm{wt} . \%$. However, conversion of reactants declined when the $\mathrm{Ni}$ loading increased to $13.5 \mathrm{wt} \%$. This indicates that a nickel loading of 9 wt.\% on Zr-Laponite(8) is sufficient for obtain-

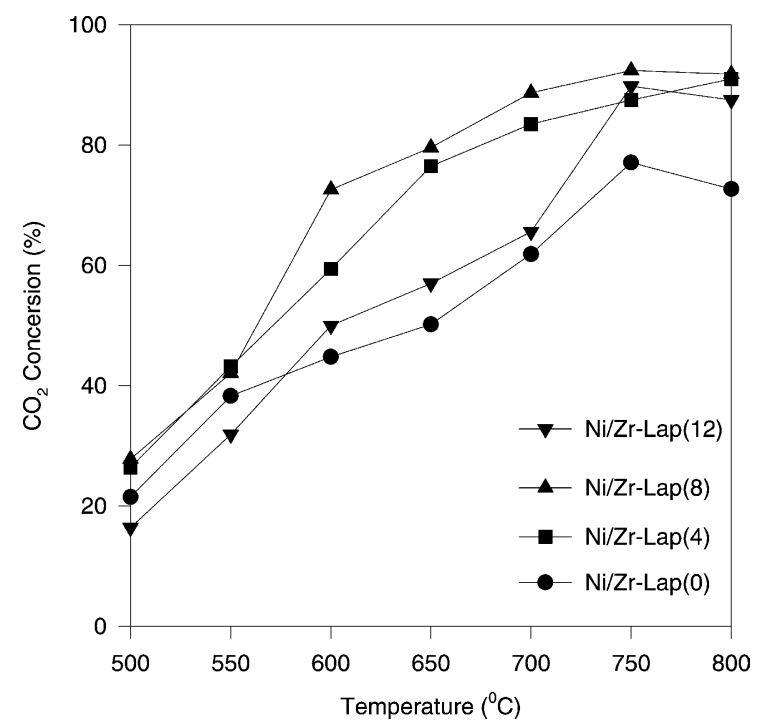

Fig. 5. $\mathrm{CO}_{2}$ catalytic conversions over various $\mathrm{Ni} / \mathrm{Zr}$-Laponite catalysts. Reaction conditions: $\mathrm{CH}_{4} / \mathrm{CO}_{2}=1: 1, P=1 \mathrm{~atm}$, $F / W=18,000 \mathrm{ml} / \mathrm{h}$ gcat. 


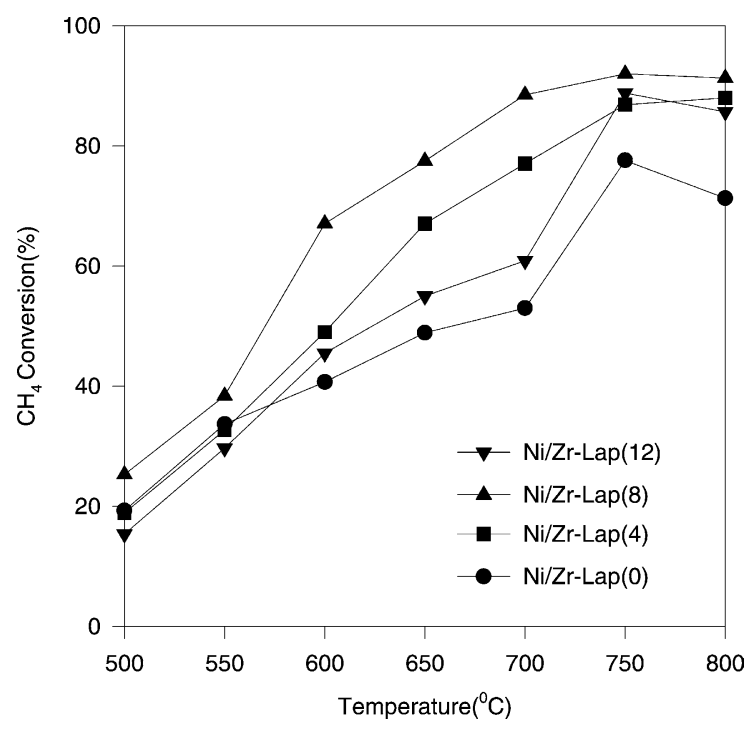

Fig. 6. $\mathrm{CH}_{4}$ catalytic conversions over various $\mathrm{Ni} / \mathrm{Zr}$-Laponite catalysts.

ing a high initial activity. The reaction data (shown in Figs. 5 and 6) show that the nature of support can have an impact on the catalytic behaviors. The activity patterns were divided into two parts, one included $\mathrm{Ni} / \mathrm{Zr}$-Laponite(0) catalyst that had only a low activity, and the other contained $\mathrm{Ni} / \mathrm{Zr}$-Laponite(4), $\mathrm{Ni} / \mathrm{Zr}$-Laponite(8) and $\mathrm{Ni} / \mathrm{Zr}$-Laponite(12) catalysts which had high activities. The initial activity of $\mathrm{Ni} / \mathrm{Zr}$-Laponite(8) is higher than catalysts $\mathrm{Ni} / \mathrm{Zr}$-Laponite(4) and Ni/Zr-Laponite(12). It is similar to the nickel supported on $\gamma-\mathrm{Al}_{2} \mathrm{O}_{3}$ with a higher initial conversion of methane and carbon dioxide, as reported by Wang and Lu [2]. As shown in Table 1, there was some relationship between the surface area and the initial activity. Some studies $[15,16]$ have also shown that the pore structure affected the catalyst activity in the carbon dioxide reforming of methane. The best catalyst is $\mathrm{Ni} / \mathrm{Zr}$-Laponite(8). Catalysts with the mesopore structure were found to have a relatively higher activity. This result is similar to the previous observations by Wang et al. [3] and Hwang et al. [4].

\subsection{Catalytic stability}

The catalytic stability experiments were conducted at $750{ }^{\circ} \mathrm{C}$ over $\mathrm{Ni} / \mathrm{Zr}$-Laponite(8), $\mathrm{Ni} / \mathrm{Zr}$-Laponite(4) and $\mathrm{Ni} / \mathrm{A}_{2} \mathrm{O}_{3}$ catalysts. The variation in $\mathrm{CO}_{2}$ and $\mathrm{CH}_{4}$
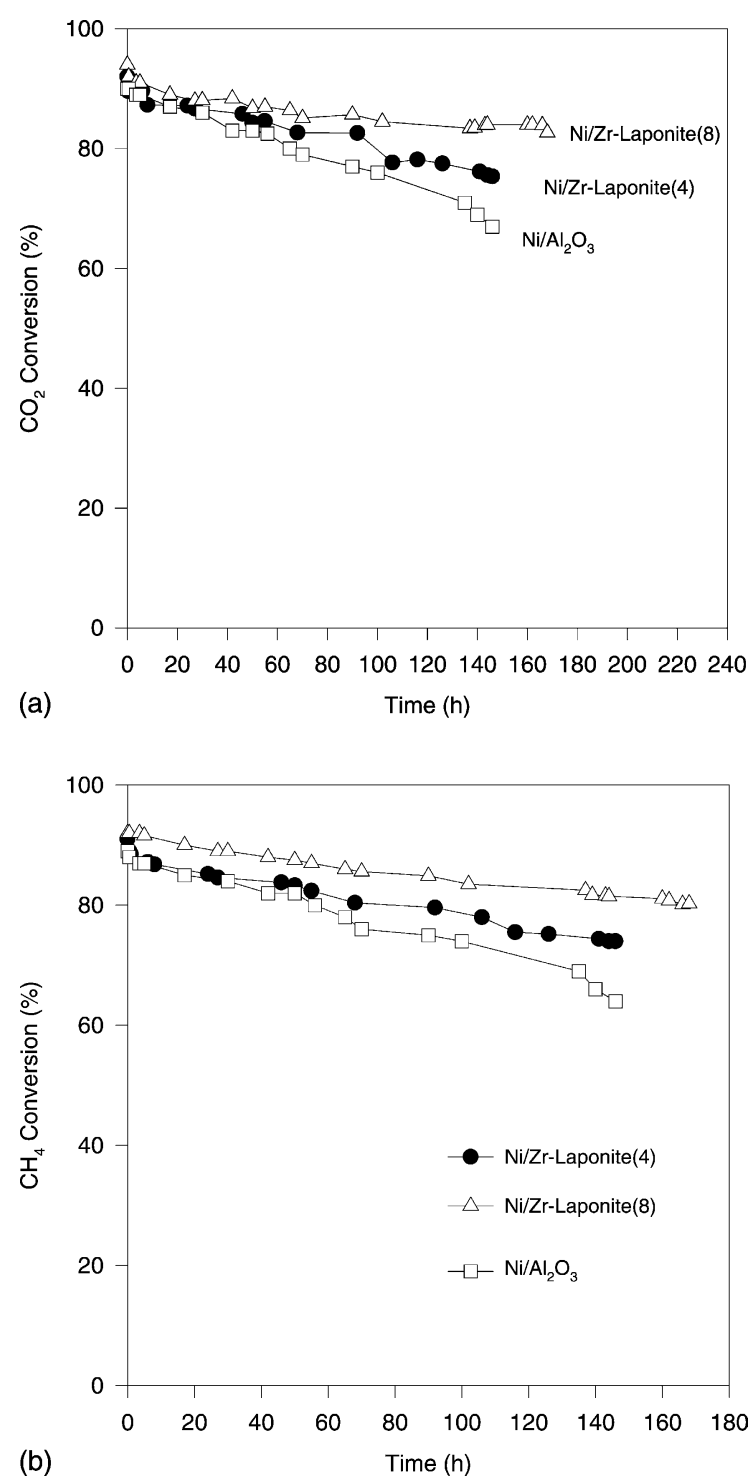

Fig. 7. Deactivation testing of the catalysts in a fixed-bed reactor at $750{ }^{\circ} \mathrm{C}$. Reaction conditions: $\mathrm{CH}_{4} / \mathrm{CO}_{2}=1: 1, P=1 \mathrm{~atm}$, flow rate: $60 \mathrm{ml} / \mathrm{min}$.

conversions as a function of time are shown in Fig. 7. It was seen that different catalysts showed deactivation to a different extent. As clearly shown, over the testing period, Ni/Zr-Laponite(4) showed moderate deactivation in the reaction. The $\mathrm{CO}_{2}$ and $\mathrm{CH}_{4}$ conversions on $\mathrm{Ni} / \mathrm{Zr}$-Laponite(4) decreased from 92 and $91 \%$ to 75 and $73 \%$. Ni/ $/ \mathrm{Al}_{2} \mathrm{O}_{3}$ catalyst showed a relatively serious deactivation, with its $\mathrm{CO}_{2}$ and $\mathrm{CH}_{4}$ conversions 
Table 2

Variation in pore structure of catalysts before and after reaction

\begin{tabular}{llll}
\hline Sample & $\begin{array}{l}\text { Surface } \\
\text { area }\left(\mathrm{m}^{2} / \mathrm{g}\right)\end{array}$ & $\begin{array}{l}\text { Pore } \\
\text { volume } \\
\left(\mathrm{cm}^{3} / \mathrm{g}\right)\end{array}$ & $\begin{array}{l}\text { Pore } \\
\text { diameter } \\
(\mathrm{nm})\end{array}$ \\
\hline $\mathrm{Ni} / \mathrm{Zr}$-Laponite(4) (fresh) & 330 & 0.306 & 3.8 \\
$\mathrm{Ni} / \mathrm{Zr}$-Laponite(4) (used) & 202 & 0.226 & 4.5 \\
$\mathrm{Ni} / \mathrm{Zr}$-Laponite(8) (fresh) & 372 & 0.354 & 3.8 \\
$\mathrm{Ni} / \mathrm{Zr}$-Laponite(8) (used) & 227 & 0.260 & 4.2 \\
\hline
\end{tabular}

decreased from 90 and $89 \%$ to 65 and $63 \%$. However, Ni/Zr-Laponite(8) has little deactivation during $170 \mathrm{~h}$ testing. The deactivation rates of these three catalysts are in the following order: $\mathrm{Ni} / \mathrm{Al}_{2} \mathrm{O}_{3}<$ $\mathrm{Ni} / \mathrm{Zr}$-Laponite(4) $<\mathrm{Ni} / \mathrm{Zr}$-Laponite(8). At a long reaction time of $170 \mathrm{~h}$, the $\mathrm{CO}_{2}$ and $\mathrm{CH}_{4}$ conversions only decreased by about 11.3 and $11.8 \%$, respectively, while the drops in conversions over $\mathrm{Ni} / \mathrm{Al}_{2} \mathrm{O}_{3}$ catalyst are 25 and $26 \%$ at $140 \mathrm{~h}$. The above results indicate that $\mathrm{Zr}$-Laponite supported $\mathrm{Ni}$ catalysts exhibit a good catalytic performance, not only a high activity, but also a longer stability.

The parameters of the porous structure for $\mathrm{Ni} / \mathrm{Zr}$-Laponite catalysts used are given in Tables 1 and 2 . The surface area and pore volume were decreased after reaction. The average pore size, however, showed an increasing trend, and the pores changed to larger pores after reaction. These results indicate that the pores were gradually blocked by the carbon deposition.

\subsection{Catalyst characterization}

As described above, there were some correspondences between pore structure and initial activity. In order to investigate the relationship between the surface structure and catalytic behaviors, it is necessary to explore the reasons for deactivation further. The structures of both fresh and used catalysts were characterized by XRD, XPS and TEM surface technologies.

Fig. 8 shows the XRD patterns of Zr-Laponite(8) and $\mathrm{Ni} / \mathrm{Zr}$-Laponite(8) with different nickel loadings. It can be observed that $9 \mathrm{wt} . \% \mathrm{Ni} / \mathrm{Zr}$-Laponite( 8 ) showed one broad diffraction $(2 \theta=30.6)$ that represents $\mathrm{ZrO}_{2}$ and two peaks $(2 \theta=44.52$ and 51.85) that can be ascribed to cubic nickel metal. It is easy to understand that the intensity of the peaks for nickel

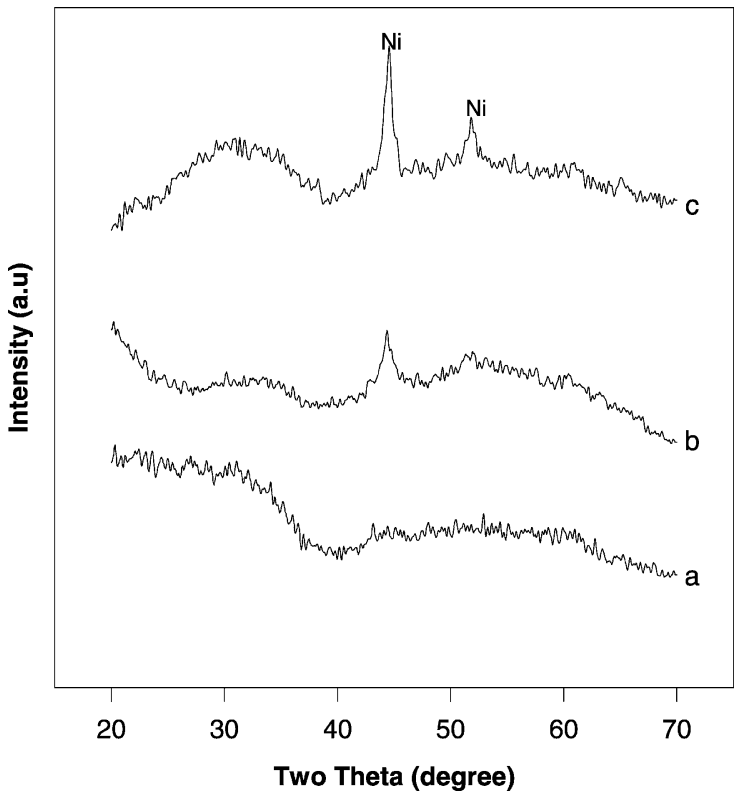

Fig. 8. XRD patterns of Zr-Laponite(8) and supported $\mathrm{Ni}$ catalysts: (a) Zr-Laponite(8), (b) $4.5 \% \mathrm{Ni} / \mathrm{Zr}$-Laponite(8), (c) $9 \% \mathrm{Ni} / \mathrm{Zr}$-Laponite(8).

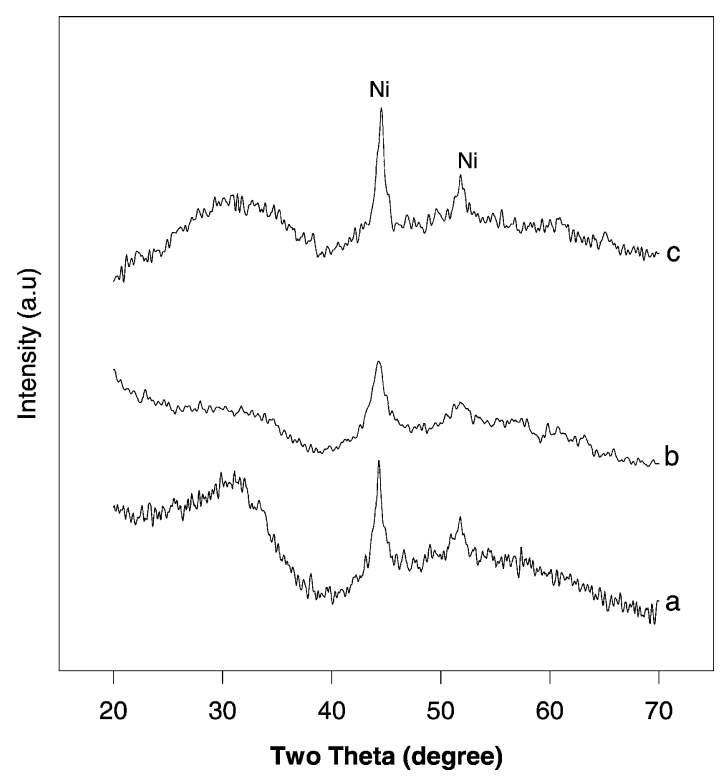

Fig. 9. XRD patterns of $\mathrm{Ni} / \mathrm{Zr}$-Laponite $(0,4,8)$ catalysts: (a) Ni/Zr-Laponite(0), (b) Ni/Zr-Laponite(4), (c) Ni/Zr-Laponite(8). 
Table 3

Physico-chemical properties of $\mathrm{Ni} / \mathrm{Zr}$-Laponite $(0,4,8)$ catalysts

\begin{tabular}{|c|c|c|c|c|}
\hline Catalysts & Ni loading (wt.\%) & Crystal phase & Ni particle size $(\mathrm{nm})$ & $\mathrm{ZrO}_{2}$ particle size $(\mathrm{nm})$ \\
\hline $\mathrm{Ni} / \mathrm{Zr}$-Laponite(0) (fresh) & 9 & $\mathrm{Ni}, \mathrm{ZrO}_{2}$ & 13.2 & 7.4 \\
\hline $\mathrm{Ni} / \mathrm{Zr}$-Laponite(4) (fresh) & 9 & $\mathrm{Ni}, \mathrm{ZrO}_{2}$ & 8.8 & - \\
\hline Ni/Zr-Laponite(4) (used) & 9 & $\mathrm{Ni}, \mathrm{ZrO}_{2}, \mathrm{C}$ & 18.9 & 8.6 \\
\hline Ni/Zr-Laponite(8) (fresh) & 9 & $\mathrm{Ni}, \mathrm{ZrO}_{2}$ & 11.1 & 3 \\
\hline Ni/Zr-Laponite(8) (used) & 9 & $\mathrm{Ni}, \mathrm{ZrO}_{2}, \mathrm{C}$ & 18.4 & 6.1 \\
\hline $\mathrm{Ni} / \mathrm{Zr}$-Laponite(8) (fresh) & 4.5 & $\mathrm{Ni}, \mathrm{ZrO}_{2}$ & 10.6 & - \\
\hline
\end{tabular}

metal increased with increasing $\mathrm{Ni}$ loadings. The XRD patterns of Ni/Zr-Laponite $(0,4,8)$ catalysts are shown in Fig. 9. For these three catalysts, the nickel metal peaks are clearly demonstrated in XRD spectra. A small difference in the intensity of the peaks of nickel metal was found among them. From the half peak width, the particle sizes of nickel metal and zirconia were obtained, the results are given in Table 3. The size of $\mathrm{Ni}$ particles and $\mathrm{ZrO}_{2}$ particles for $\mathrm{Ni} / \mathrm{Zr}$-Laponite(4) and $\mathrm{Ni} / \mathrm{Zr}$-Laponite(8) catalysts are smaller, about 10 and $3 \mathrm{~nm}$, respectively, while for the fresh $\mathrm{Ni} / \mathrm{Zr}$-Laponite $(0)$ the sizes are larger, $\mathrm{Ni}$ particles (about $13 \mathrm{~nm}$ ) and $\mathrm{ZrO}_{2}$ particles (about $7.4 \mathrm{~nm}$ ).

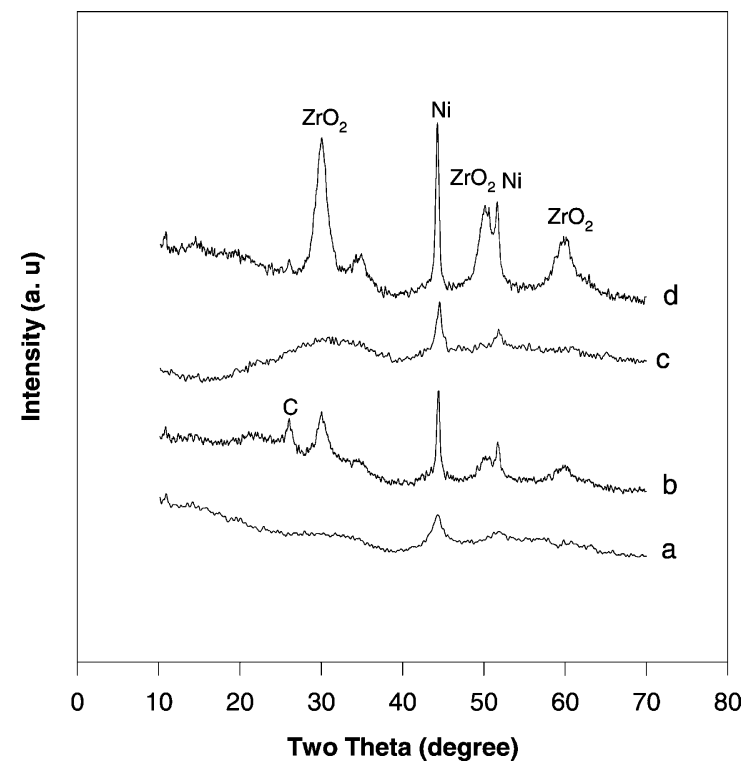

Fig. 10. XRD patterns of fresh and used Ni/Zr-Laponite catalysts: (a) Ni/Zr-Laponite(4) fresh, (b) Ni/Zr-Laponite(4) used, (c) $\mathrm{Ni} / \mathrm{Zr}$-Laponite(8) fresh, (d) Ni/Zr-Laponite(8) used.
Generally, for supported metal catalysts, the metal particle size depends on the support porosity and the metal-support interaction. For Ni/Zr-Laponite(0), the lower porosity of support resulted in less dispersion of metal and thus larger particle size. The well-developed porosity of Zr-Laponite(4) and Zr-Laponite(8) led to higher dispersion and smaller particles of nickel metal. Combined with surface area data listed in Table 1, such results show that there was a relationship between metal crystallite size and the pore structure of the support. The support with larger porosity has a smaller nickel particle size. During the impregnation process, metal ions could be easily diffused into the pores of porous support, leading to high dispersion, whereas they would deposit on the outer surface of the

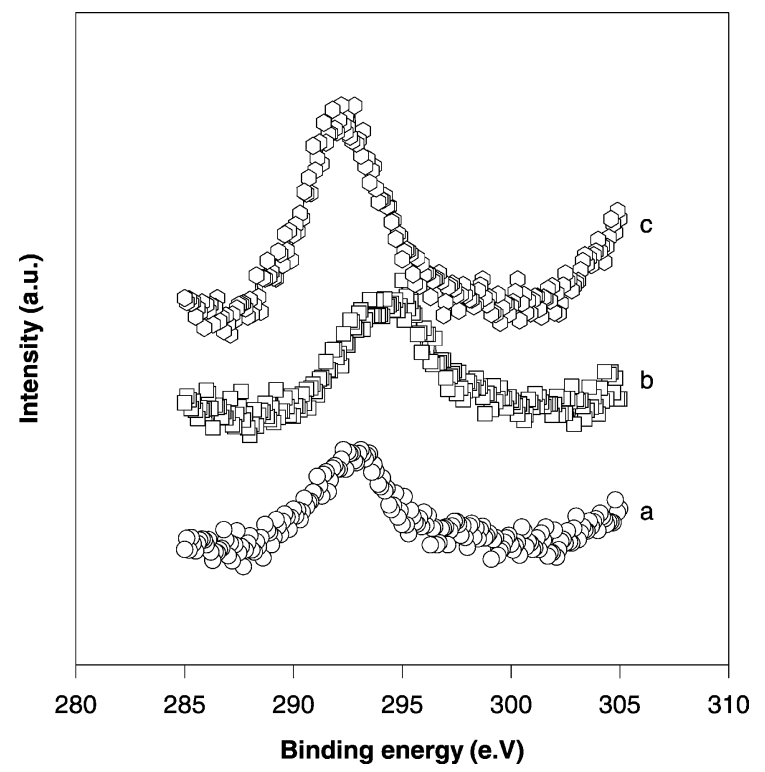

Fig. 11. C 1s spectra of various Ni catalysts before reaction: (a) Ni/Zr-Laponite(8), (b) Ni/Zr-Laponite(4), (c) Zr-Laponite(8). 
Table 4

Surface chemical composition of nickel catalysts before and after reaction

\begin{tabular}{|c|c|c|c|c|c|c|}
\hline Catalyst & & $\mathrm{C}(\%)$ & $\mathrm{O}(\%)$ & $\mathrm{Zr}(\%)$ & $\mathrm{Ni}(\%)$ & $\mathrm{Si}(\%)$ \\
\hline \multirow[t]{2}{*}{ Ni/Zr-Laponite(4) } & Fresh & 9.4 & 62.7 & 4.6 & 9 & 14.3 \\
\hline & Used & 87.6 & 9.3 & 0.7 & - & 2.3 \\
\hline \multirow[t]{2}{*}{$\mathrm{Ni} / \mathrm{Zr}$-Laponite(8) } & Fresh & 9.1 & 65 & 4.7 & 2.1 & 19.1 \\
\hline & Used & 22.8 & 54.6 & 4.2 & 0.29 & 18.1 \\
\hline
\end{tabular}

nonporous support and aggregate to form large particles. This is similar to Wang's viewpoint on oxide supported Ni catalysts [1].

Fig. 10 shows the XRD patterns of fresh and used $\mathrm{Ni} / \mathrm{Zr}$-Laponite $(4,8)$ catalysts. As described above, the fresh catalysts showed only the form of two peaks $(2 \theta=44.52$ and 51.85) ascribed to nickel metal and one broad peak $(2 \theta=30.6)$ ascribed to zirconia. After a long-time reaction, the intensity for diffraction peaks of cubic nickel metal and zirconia increased. The new diffraction peaks ( $2 \theta=50.67$ and 60.46$)$ of cubic zirconia and carbon appeared, which shows clearly that there was carbon deposition on the catalyst surface. Nickel particle size and zirconia particle size were calculated for these catalysts, the results are shown in Table 3. It is found that the used catalysts have big-

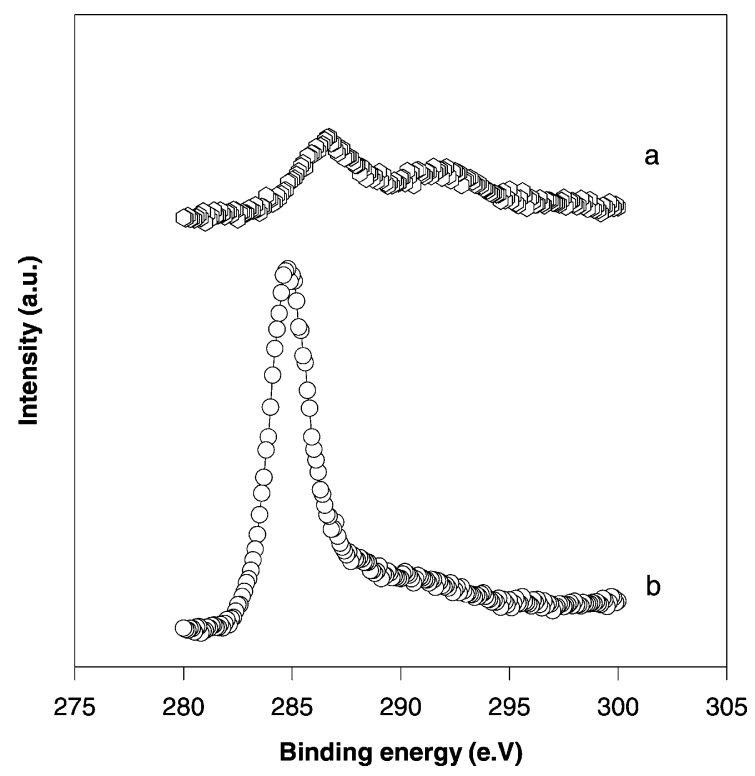

Fig. 12. C 1s spectra of various Ni catalysts after reaction: (a) $\mathrm{Ni} / \mathrm{Zr}$-Laponite(8), (b) Ni/Zr-Laponite(4). ger particle sizes (18 and $6 \mathrm{~nm}$ for nickel metal and zirconia, respectively). The sintering of nickel metal and zirconia support is responsible for the increase of particle size after a relatively long-time reaction.

The surface properties of catalysts are analyzed by the XPS technique, and the chemical composition of different elements and $\mathrm{C} 1 \mathrm{~s}$ spectra are shown in Table 4 and Figs. 11 and 12, respectively. XPS results gave various surface elemental concentrations on the catalyst surface. The fresh catalysts show that all elements have a similar surface concentration. $\mathrm{Ni}$ surface concentrations of catalysts show that the fresh $\mathrm{Ni} / \mathrm{Zr}$-Laponite(4) and Ni/Zr-Laponite(8) are similar, but the used Ni/Zr-Laponite(4) has a trace of nickel content. This is due to the larger amount of carbon deposited on the catalyst surface, which prevents the detection of chemical nickel. The $\mathrm{C} 1 \mathrm{~s}$ peaks on the fresh catalyst appear at the higher binding energy

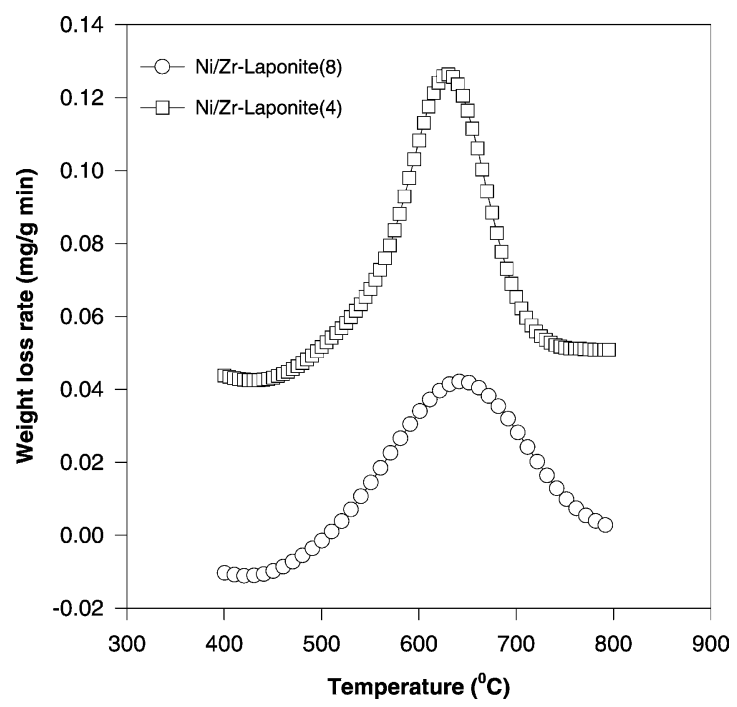

Fig. 13. TPO profiles of carbonaceous species formed on the catalysts after reaction at $750^{\circ} \mathrm{C}$. 
$(>290 \mathrm{eV})$, as well as $\mathrm{Zr}$-Laponite(8) support, indicating the presence of surface carbonate $\left(\mathrm{CO}_{3}{ }^{-}\right)$ species. The surface carbonate species is expected to be formed due to the interaction of $\mathrm{CO}_{2}$ from the atmosphere.

\subsection{Carbon deposits}

From Table 4, it is apparent that there were carbon deposits on these catalysts after reaction. The concentration of surface carbon on $\mathrm{Ni} / \mathrm{Zr}$-Laponite(4) is much higher than that on $\mathrm{Ni} / \mathrm{Zr}$-Laponite(8) catalyst, which shows lower surface carbon deposition. Fig. 12 shows that two peaks appear in $\mathrm{C} 1 \mathrm{~s}$ spectra of $\mathrm{Ni} / \mathrm{Zr}$-Laponite(8) catalyst. One located at $287.3 \mathrm{eV}$, another at $292.1 \mathrm{eV}$, which can be ascribed to $\mathrm{COC}$ and $\mathrm{CO}_{3}{ }^{-}$carbon components, respectively. For Ni/Zr-Laponite(4) catalyst, the C 1 s component is predominantly at $285 \mathrm{eV}$.

The amount of carbon deposited on the catalysts in deactivation tests was measured by TPO experiments on TGA. The weight loss profile between 400 and $800^{\circ} \mathrm{C}$ is presented in Fig. 13. It is seen that carbon began to be oxidized at $450^{\circ} \mathrm{C}$. For Ni/Zr-Laponite(4) and $\mathrm{Ni} / \mathrm{Zr}$-Laponite(8) used for 140 and $170 \mathrm{~h}$, respectively, peaks appeared at a similar temperature, close to $635^{\circ} \mathrm{C}$. The different amount of carbon that resulted indicates that the $\mathrm{Ni} / \mathrm{Zr}$-Laponite(8) catalyst had the lower coking activity, while $\mathrm{Ni} / \mathrm{Zr}$-Laponite(4) catalyst showed higher coking activity. The difference can be evaluated as being as great as twofold.

TEM was used to characterize the morphologies of fresh and used $\mathrm{Ni} / \mathrm{Zr}$-Laponite(4) catalysts. As shown in Figs. 14 and 15, the fresh catalyst shows nickel nanoparticles in the order of $7-10 \mathrm{~nm}$. No forms of carbon are visible. After $140 \mathrm{~h}$ reaction, a number of heterogeneous carbon particles are found, with clear graphitic phases observed. Thus, the size of nickel particles increased after a long period of high temperature reaction. So far as the deactivation caused by carbon deposition is concerned, XRD, XPS and TPD measurements have shown that larger amounts of carbons are deposited on $\mathrm{Ni} / \mathrm{Zr}$-Laponite(4) catalyst.

Based upon the characterization results of catalyst structure and carbon deposits, and the long-time reaction data. Both the carbon deposition and sintering are related to deactivation. It seems to be most likely that methane adsorbed on nickel particles and $\mathrm{CO}_{2}$

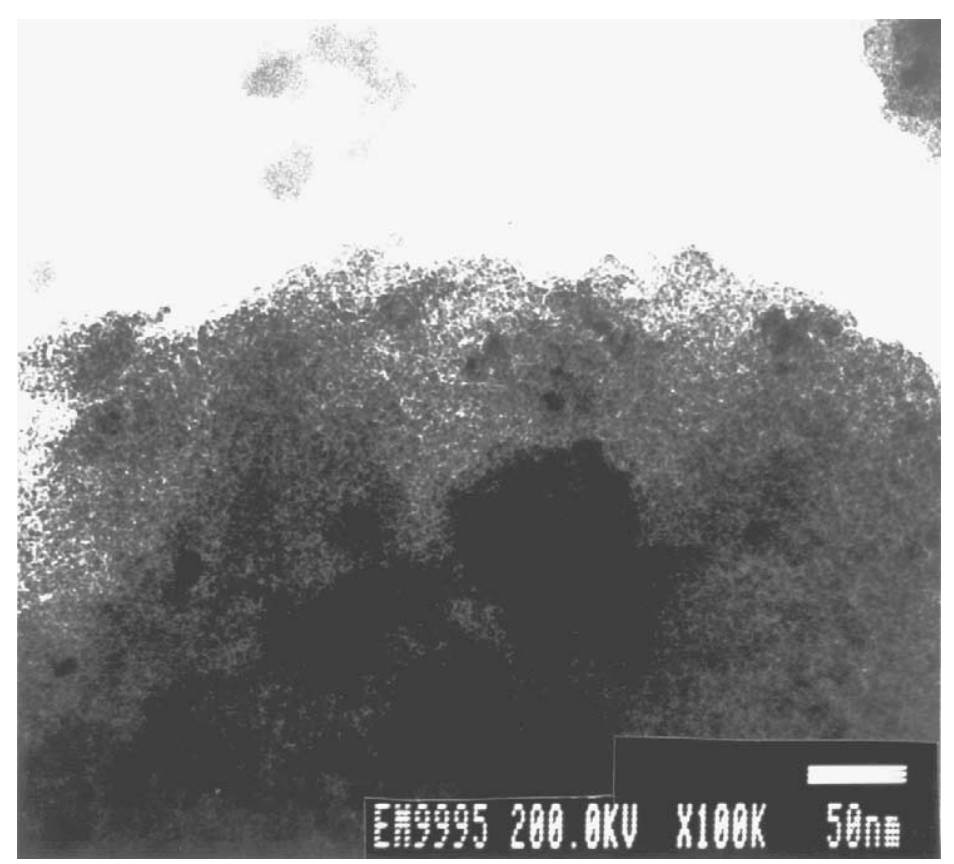

Fig. 14. TEM image of fresh Ni/Zr-Laponite(4) catalyst. 

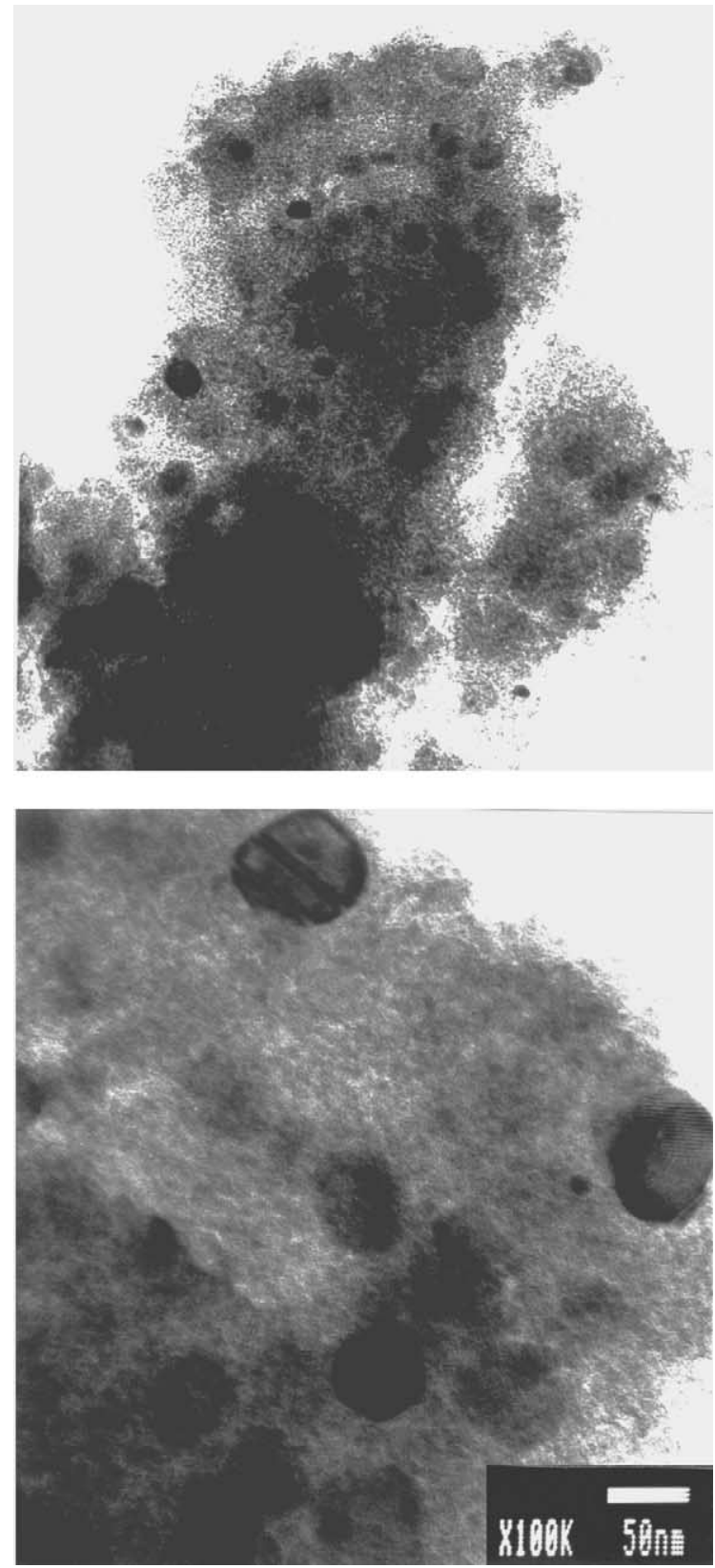

Fig. 15. TEM image of used Ni/Zr-Laponite(4) catalyst after $140 \mathrm{~h}$ at $750{ }^{\circ} \mathrm{C}$.

adsorbed on support oxide zirconia. The reforming reaction of $\mathrm{CO}_{2}$ with $\mathrm{CH}_{4}$ is expected to proceed at the interface of nickel and zirconia by the following steps: (1) dehydrogenation of methane to form surface car- bon and hydrogen; (2) dissociative adsorption of $\mathrm{CO}_{2}$; and (3) reduction of $\mathrm{CO}_{2}$ to $\mathrm{CO}$. The catalyst composites small size zirconia and well dispersed nickel particles with small size, perhaps has an active phase structure such as $\mathrm{Ni}-\mathrm{O}-\mathrm{Zr}$ is beneficial to prevent to carbon deposit and sintering.

\section{Conclusions}

Zirconia pillared laponite clays are promising catalyst supports for carbon dioxide reforming of methane. The pore structure and surface nature of these materials can be tailored to obtain supports with higher surface area, prepare and obtain well-dispersed $\mathrm{Ni}$ catalysts. Ni/Zr-Laponite(8) was preferable to either $\mathrm{Ni} / \mathrm{Zr}$-Laponite(4) and $\mathrm{Ni} / \mathrm{Al}_{2} \mathrm{O}_{3}$ catalysts, in terms of catalytic conversion and stability. Carbon deposition on catalysts was also affected by the properties and structure of the support. In addition, sintering of nickel metal and zirconia was another factor responsible for catalyst deactivation. Among the catalysts investigated in this work, $\mathrm{Ni} / \mathrm{Zr}$-Laponite(8) catalyst gave a high conversion and a long-term stability, and is therefore a promising catalyst for potential application in dry reforming of methane.

\section{Acknowledgements}

We thank Dr. Barry Wood of the Department of Chemistry, University of Queensland, Australia, for the XPS measurements, Dr. John Drennan of Center for Microscopy \& Microanalysis University of Queensland, Australia, for TEM analysis, and Mr. L.K. Bekessy of the Department of Mining and Material Engineering University of Queensland, Australia, for XRD measurements. Financial support from the Australia Research Council (ARC) and partial financial assistance from China '10.5' 863 Programme (Project 2001AA324050) are also greatly appreciated.

\section{References}

[1] S. Wang, G.Q. Lu, Appl. Catal. B: Envirron. 16 (1998) 269.

[2] S. Wang, G.Q. Lu, Ind. Eng. Chem. Res. 38 (1999) 2615. 
[3] S. Wang, H.Y. Zhu, G.Q. Lu, J. Colloid Interface Sci. 204 (1998) 28.

[4] K.S. Hwang, H.Y. Zhu, G.Q. Lu, Catal. Today 68 (2001) 183.

[5] V.R. Choudhary, A.S. Mamman, B.S. Uphade, R.E. Babcock, Book of abstracts, in: Proceedings of the 219th ACS National Meeting, San Francisco, CA, March 26-30, 2000, American Chemical Society, Washington, DC, Coden: 69CLAC Conference.

[6] K. Seshan, H.M. Barge, W. Hally, A.N.J. Keulen, J.R.H. Joss, Stud. Surf. Sci. Catal. 81 (1994) 285

[7] J.A. Lercher, J.H. Bitter, W. Hally, W. Niessen, K. Seshan, Stud. Surf. Sci. Catal. 101 (1996) 463

[8] J.M. Wei, B.Q. Xu, J.L. Li, Z.X. Cheng, Q.M. Zhu, Appl. Catal. A: Gen. 196 (2000) L167.
[9] X.S. Li, J.S. Chang, S.E. Park, React. Kinet. Catal. Lett. 67 (1999) 375.

[10] X.S. Li, J.S. Chang, E.K. Lee, S.E. Park, React. Kinet. Catal. Lett. 67 (1999) 383.

[11] H.Y. Zhu, S. Yamanaka, J. Chem. Soc., Faraday Trans. 93 (1997) 477.

[12] A. Gil, L.M. Gandia, M.A. Vicente, Catal. Rev.-Sci. Eng. 42 (2000) 145.

[13] Y. Schuurman, V.C.H. Kroll, P. Perreira-Aparicio, C. Mirodatos, Catal. Today 38 (1997) 129.

[14] Z.F. Yan, R.G. Ding, L.H. Song, L. Qian, Energy and Fuels 12 (1998) 1114.

[15] E. Ruckenstein, Y.H. Hu, J. Catal. 162 (1996) 230.

[16] S.B. Tang, F.L. Qiu, S.J. Lu, Catal. Today 24 (1995) 253. 